\title{
METODE STRUKTURAL ANALITIK SINTETIK DALAM PEMBELAJARAN ANAK DISLEKSIA
}

\author{
Fitria Martanti
}

Fakultas Agama Islam Universitas Wahid Hasyim Semarang

Email: fitriamartanti@unwahas.ac.id

\begin{abstract}
ABSTRAK
Membaca merupakan salah satu kemampuan penting yang perlu dimiliki oleh anak. Tidak semua anak dapat belajar membaca dengan mudah, pada beberapa kasus ditemukan anak yang kesulitan belajar membaca atau dikenal dengan istilah disleksia. Penelitian ini merupakan penelitian lapangan (field research). Pendekatan penelitian yang digunakan adalah pendekatan kualitatif, artinya data yang dikumpulkan bukan merupakan angka-angka, melainkan data tersebut berasal dari wawancara, catatan lapangan dan dokumen resmi lainnya. Berdasarkan hasil penelitian di SDN Watuaji 1 Jepara dapat diketahui bahwa beberapa anak yang mengalami kesulitan membaca disebabkan oleh perhatian orang tua yang kurang dan faktor intelegensi maupun sosio-ekonomi. Pelaksanaan metode struktural analitik sintetik dalam pembelajaran anak disleksia dapat membantu anak dalam mempermudah belajar membaca. Pelaksanaan metode struktural analitik sintetik dilakukan dengan menyajikan kalimat secara utuh, kemudian kalimat itu dianalisis menjadi kata, suku kata, dan huruf, serta unsur huruf tersebut dirangkaikan hingga menjadi kalimat kembali. Penggunaan metode struktural analitik sintetik selain dapat membantu kesulitan membaca juga dapat meningkatkan kerjasama anak dalam proses pembelajaran.
\end{abstract}

Kata kunci: Metode, Struktural Analitik Sintetik, disleksia. 


\begin{abstract}
Reading is one of the important skills that children need to have. Not all children can learn to read easily, in some cases found children who have difficulty learning to read or dyslexia. This is a field research. The research approach used is a qualitative approach, meaning that data collected is not a number, but the data comes from interviews, field notes and other official documents. Based on the results of research at SDN Watuaji 1 Jepara can be seen that some children who have difficulty reading caused by the attention of parents who lack and intelligence and socio-economic factors. The implementation of synthetic analytic structural method in children learning dyslexia can help children in facilitate learning to read. The implementation of the synthetic analytic structural method is done by presenting the whole sentence, then the sentence is analyzed into words, syllables and analyzed into letters and the elements of the letters are coupled to a back sentence. The use of structural analytic synthetic methods besides can help reading difficulties can also improve the cooperation of children in the learning process.
\end{abstract}

\title{
Keywords: Synthetic Analytical Structural Method, dyslexia.
}

\section{A. PENDAHULUAN}

Membaca merupakan kemampuan penting yang perlu dimiliki oleh anak. Kegiatan membaca dapat membantu anak dalam menerima ataupun menggali pengetahuan dan keterampilan. Kenyataan di lapangan menunjukkan bahwa tidak semua anak dapat membaca dengan mudah. Beberapa anak dijumpai mengalamai hambatan ketika belajar membaca. Kesulitan membaca tentunya akan mengakibatkan kesulitan dalam mempelajari berbagai bidang studi lainnya. Pada dasarnya kesulitan belajar dapat dibedakan menjadi kesulitan belajar yang berhubungan dengan perkembangan yang mencakup gangguan motorik dan persepsi, kesulitan belajar bahasa dan komunikasi, kesulitan belajar dalam penyesuaian perilaku sosial. Kesulitan belajar yang lainnya adalah berkaitan dengan kesulitan akademik yang mencakup adanya kegagalankegagalan pencapaian prestasi akademik sesuai dengan kapasitas yang diharapkan. Kegagalan-kegagalan tersebut mencakup penguasaan keterampilan dalam membaca, menulis, atau matematika. ${ }^{1}$

1. Mulyono Abdurrahman, Pendidikan Bagi anak Berkesulitan Belajar (Jakarta: Rineka Cipta, 2003), hlm. 11. 
Kondisi kesulitan belajar pada anak memang tidak dapat disamakan antara anak yang satu dengan yang lainnya. Perkembangan anak yang tidak sama secara nyata akan turut mempengaruhi perkembangan belajar anak. Hambatan dalam perkembangan anak tentunya akan menjadi penyebab terjadinya hambatan dalam belajar. Hal tersebut tergantung dari hambatan apa yang menyertai perkembangan anak dalam belajar.

Membaca merupakan kemampuan dasar yang dapatmengantarkan anak memahami ilmu pengetahuan yang dipelajarinya. Banyak guru yang tidak mampu memahami kelemahan anak dalam belajar, terutama dalam memahami penyebab anak mengalami kesulitan membaca. Anggapan bahwa anak yang tidak dapat membaca merupakan anak yang bodoh, padahal dalam beberapa kasus anak yang mengalami kesulitan dalam membaca, memiliki kemampuan intelgensi yang cukup tinggi. Dengan demikian, perlu pemahaman guru tentang anak yang mengalami kesulitan membaca dan metode yang tepat dalam mengajarkan membaca pada anak.

Membaca merupakan keterampilan mengartikan lambang-lambang, sebagai proses berpikir, mencakup aktivitas pengenalan kata, pemahaman literal, interpretasi, membaca kritis dan pemahaman kreatif. ${ }^{2}$ Rahim Mempertegas bahwa membaca merupakan serangkaian proses visual, berpikir, linguistik dan proses metakognitif. Proses visual yakni proses menerjemahkan simbol ke dalam suatu bunyi. Membaca sebagai proses berpikir yaitu membaca yang mencakup pengenalan kata, pemahaman literal, interpretasi, membaca kritis dan membaca kreatif. Membaca sebagai proses linguistik, dengan skemata pembaca membantunya untuk membangun makna, sedangkan untuk proses metakognif, melibatkan perencanaan, pembetulan strategi dan pengevaluasian. Membaca juga dapat diartikan sebagai kegiatan untuk mendapatkan makna dari apa yang tertulis dalam teks. ${ }^{3}$ Membaca dalam arti lain disebut sebagai kegiatan memahami bahasa tulis. ${ }^{4}$ Pesan dari sebuah teks atau barang cetak lainnya tentunya dapat diterima apabila pembaca dapat membacanya dengan tepat, sehingga pembaca akan salah menerima pesan manakala pembaca salah dalam membacanya.

2. Farida Rahim, Pengajaran Membaca di Sekolah Dasar (Jakarta: Bumi Aksara, 2007), hlm. 7.

3. Iskandar Wassid dan Dadang Sunendar, Strategi Pembelajaran Bahasa (Bandung: Remaja Rosdakarya, 2008), hlm. 246.

4. Puji Santoso, Materi dan Pembelajaran Bahasa Indonesia SD (Jakarta: Universitas Terbuka, 2008), hlm. 63. 
Segala hal yang menyertai perkembangan anak tentunya akan turut mempengaruhi perkembangan belajar anak. Terkadang dalam masa perkembangan akan terjadi hambatan, kemungkinan penyebab terjadinya hambatan perkembangan belajar adalah karena hambatan perkembangan anak yang berbeda-beda. Hambatan atau kesulitan belajar pada anak yang berkaitan dengan siswa itu sendiri biasannya disebabkan karena kondisi fisiologis dan psikologis siswa. ${ }^{5}$

Kemampuan membaca pada anak normal umumnya pada usia enam atau tujuh tahun, akan tetapi kemampuan membaca pada anak juga dipengaruhi oleh kesiapan untuk memulai pengajaran membaca yang dipegaruhi oleh kesadaran fonemis. Istilah ini meliputi banyak aspek kepekaan anak terhadap struktur bunyi kata lisan, menentukan kemampuan memetakan bunyi kesimbol yang penting untuk membaca, menulis, dan mengeja. Faktor inilah yang nantinya menjadi dasar untuk membedakan kemampuan membaca pada anak normal dan pembaca lemah. Teori kesiapan ini sejalan dengan pendapat klasik dari Havighurst bahwa mengajar haruslah pada saat anak berada dalam kondisi saat tepat untuk belajar. ${ }^{6}$

Mengatasi kemampuan anak dalam membaca tentunya harus dilihat dari faktor yang menyebabkan anak mengalami kekurangan dalam membaca. Kemampuan anak dalam membaca apabila tidak segera diatasi maka akan dapat menyebabkan masalah lain dalam belajar. Kesulitan membaca merupakan bentuk kesulitan dalam mengubah bahasa tulisan menjadi bahasa lisan, kelancaran dalam membaca dan memahami arti bacaan. Memahami berbagai masalah kesulitan membaca pada anak sekolah dasar tentunya harus memahami aspek penting dalam membaca, yaitu: 1) berkaitan dengan keterampilan yang bersifat mekanis seperti pengenalan bentuk huruf, pengenalan unsur-unsur linguistik (fonem, kata, frase, pola klausa, kalimat, dan lain-lain), pengenalan hubungan pola ejaan dan bunyi, dan kecepatan membaca ke taraf lambat. 2) keterampilan yang bersifat pemahaman, seperti memahami pengertian sederhana, memahami signifikansi atau makna, penilaian dan kecepatan membaca yang fleksibel.

Kriteria diagnostik pada anak disleksia yang digunakan dalam Diagnostic and Statistical Manual of Mental Disorder-IV (DSM-IV) pada dasarnya dapat dilihat dari: 1)prestasi membaca yang terukur secara individual, dari ketepatan (kebenaran)

5. Sumadi Suryabrta, Psikologi Pendidikan (Jakarta: Grafindo, 2012), hlm. 233.

6. M. Fauzil Adhim, Membuat Anak Gila Membaca (Bandung: Mizan Media Utama, 2004), hlm. 29. 
membaca dan pemahaman membaca adalah di bawah usia kronologis. Hal ini dapat terlihat dari adanya penyimpangan dalam membaca, penggantian huruf atau kata dalam membaca, dan penghilangan huruf dalam membaca. Selain itu, juga terdapat kecepatan membaca yang lambat dan pemahaman bacaan yang kurang tepat, baik dalam membaca nyaring atau membaca dalam hati. 2) gangguan prestasi membaca akan mempengaruhi prestasi akademik dan atau kegiatan harian yang berkaitan dengan kemampuan membaca. 3) jika terdapat gangguan penglihatan, biasanya dampak kesulitan membaca juga mengikutinya.

Disleksia merupakan hambatan belajar dalam bahasa yang dapat mempengaruhi kemampuan dalam dalam pengenalan huruf, seperti membaca, menulis dan mengeja. Disleksia bercirikan kelemahan akan menggunakan kode atau simbol dan kelemahan dalam mengeja sebagaimana dalam pengucapannya. Ciri pertama adalah kesulitan dalam bahasa wicara dan keterbatasan dalam ingatan jangka pendek. Ciri kedua adalah kelemahan dalam pemahaman (akibat keterbatasan dalam penggunaan simbol atau memori jangka pendek) dan kelemahan dalam menulis sebagaimana kesulitannya dalam memperoleh informasi untuk belajar.

Kesulitan membaca pada anak pada dasarnya dipengaruhi oleh beberapa faktor, dan tentunya faktor yang mempengaruhi kesulitan membaca pada anak yang satu berbeda dengan faktor kesulitan membaca pada anak yang lain. Adapun faktorfaktor yang dapat mempengaruhi kesulitan membaca adalah: 1) faktor fisiologis yang mencakup kesehatan fisik, pertimbangan neurologis dan jenis kelamin. Gangguan juga dapat terjadi karena belum berkembangnya kemampuan dalam membedakan simbol-simbol cetakan, seperti huruf, angka dan kata. Pada anak disleksia, faktor yang menyebabkan ketidakmampuan membaca yakni adanya keterbatasan sistem neurologis atau disfungsi otak. 2) faktor intelektual, yaitu kemampuan global atau umum yang dimiliki oleh individu untuk bertindak sesuai dengan tujuan, berpikir rasional dan berbuat secara efektif terhadap lingkungan, termasuk dalam kegiatan membaca. 3) faktor lingkungan yang mencakup latar belakang dan pengalaman siswa di rumah dan sosial ekonomi di keluarga siswa. 4) Faktor Psikologis yang mencakup motivasi, minat, kematangan sosial, emosi dan penyesuaian diri. Berdasarkan uraian sebelumnya dapat disimpulkan bahwa faktor yang dapat mempengaruhi kemampuan membaca yakni, faktor fisiologis (kesehatan fisik), faktor intelektual (kemampuan umum), faktor lingkungan (keluarga, sosial dan ekonomi), dan faktor psikologis.

Metode yang dapat digunakan dalam mengatasi masalah kesulitan membaca sangat beragam salah satunya yaitu metode Struktural Analitik Sintetik (SAS). 
Struktural dapat diartikan dengan menampilkan keseluruhan (kalimat utuh), Analitik merupakan proses penguraian kalimat menjadi unsur bahasa terkecil, dan Sintetik dengan melakukan penggabungan kembali kepada bentuk struktural semula. Penggunaan metode ini diyakini dapat membantu sedikit demi sedikit kemampuan anak dalam membaca, sehingga dalam penggunaannya perlu dilakukan agar anakanak yang mengalami kesulitan membaca dapat terbantu.

Berdasarkan hasil penelitian yang telah dilakukan dapat dilihat bahwa beberapa siswa kelas 2 SDN Watuaji 01 Jepara mengalami kesulitan dalam belajar membaca. Hal tersebut dapat dilihat dari kesalahan membaca seperti kesulitan dalam mengucapkan bunyi huruf diftong (ng, ny), adanya pengilangan huruf, kesalahan pengucapan huruf dalam kata dan lambatnya anak dalam membaca. Siswa yang mengalami kesulitan membaca tersebut, juga mengalami kesulitan dalam pemahaman pada proses belajar mengajar, sehingga menyebabkan hasil belajar siswa dalam beberapa mata pelajaran mencapai hasil di bawah KKM.

Melihat pentingnya penanaman kemampuan membaca pada anak, penelitian ini bermaksud untuk meneliti permasalahan yang berkaitan dengan kesulitan membaca pada anak atau lebih dikenal dengan istilah disleksia. Penelitian ini bertujuan untuk mencari penyebab anak-anak yang mengalami kesulitan dalam membaca, dan melihat implementasi metode struktural sintetik analitik dalam pembelajaran anak disleksia.

\section{B. METODE PENELITIAN}

Jenis penelitian ini adalah penelitian lapangan (field research). Penelitian lapangan dilakukan dengan terjun secara langsung ke lokasi sumber penelitian untuk memperoleh data yang akurat dan obyektif. Penelitian lapangan dilakukan untuk mengungkap fakta kehidupan di lapangan. ${ }^{7}$ Pendekatan penelitian yang digunakan adalah pendekatan kualitatif, artinya data yang dikumpulkan bukan merupakan angka-angka, melainkan data tersebut berasal dari wawancara, catatan lapangan, dan dokumen resmi lainnya, sehingga yang menjadi tujuan dari penelitian ini adalah ingin menggambarkan realita empirik dibalik fenomena yang terjadi secara mendalam dan rinci. Oleh karena itu, penggunaan pendekatan kualitatif dalam penelitian ini adalah dengan mencocokkan antara realita empirik dengan teori yang berlaku dengan menggunakan metode deskriptif. ${ }^{8}$

7. Marhaeni, Metode Penelitian (Jakarta: PT. Bumi Aksara, 2005), hlm. 25.

8. J. Lexy Moleong, Metode Penelitian Kualitatif (Bandung: Remaja Rosdakarya, 2007), hlm. 131. 
Penelitian kualitatif dilakukan dengan membuat deskripsi, gambaran sistematis, faktual dan akurat mengenai fakta-fakta, sifat-sifat serta hubungan antara berbagai fenomena yang diteliti secara mendalam. Dari deskripsi yang dilakukan berkaitan dengan permasalahan yang diteliti maka dapat diperoleh gambaran secara jelas terkait penggunaan metode struktural analitik sintetik dalam pembelajaran anak disleksia di lokasi penelitian.

Subyek dalam penelitian ini adalah anak-anak kelas 2 yang mengalami kesulitan membaca, yakni sejumlah 3 orang anak dari keseluruhan siswa yang berjumlah 15 orang siswa. Teknik pengumpulan data dalam penelitian ini dengan menggunakan teknik wawancara, observasi dan dokumentasi. Adapun analisis data dalam penelitian ini diawali dengan menelaah seluruh data yang terkumpul dari hasil wawancara, observasi dan dokumentasi, mengadakan reduksi data yang dilakukan dengan membuat rangkuman inti, proses dan pernyataan-pernyataan yang perlu, menyusun data dalam satuan-satuan atau mengorganisasikan pokok-pokok pikiran, mengadakan pemeriksaan keabsahan data atau memberi makna pada hasil penelitian dengan cara menghubungkan teori dan yang terakhir adalah menarik simpulan.

\section{HASIL PENELITIAN DAN PEMBAHASAN}

Berdasarkan hasil penelitian yang dilakukan dapat diketahui bahwa anak-anak yang mengalami kesulitan membaca disebabkan oleh beberapa faktor utama, sebagai berikut:

1. Kurangnya perhatian orang tua

Berdasarkan hasil penelitian dapat diketahui bahwa 3 anak yang mengalami kesulitan membaca disebabkan karena kurangnya perhatian orang tua. Hal ini karena orang tua murid merupakan pekerja yang waktunya tersita untuk bekerja di luar rumah, sehingga waktunya untuk mendampingi anak untuk belajar juga kurang bahkan tidak ada waktu sama sekali untuk mendampingi anak dalam belajar. Belajar membaca bagi anak yang kesulitan membaca tentunya tidak hanya waktu pembelajaran di kelas saja, tetapi yang terpenting juga pada saat belajar di rumah.

Perhatian orang tua merupakan faktor penting yang mempengaruhi motivasi anak dalam belajar, bila orang tua tidak memperhatikan anak maupun mendampingi anak dalam belajar, maka akan mempengaruhi motivasi anak dalam belajar. Perhatian orang tua dapat dilihat dari keberadaan orang tua dalam memperhatikan 
anak belajar, membimbing dan mengarahkan anak dalam belajar, serta mengajari anak membaca maupun menulis. Anak yang didampingi orang tuannya selama belajar, tentunya akan memiliki hasil belajar yang berbeda bila dibandingkan anak yang tidak didampingi secara langsung oleh orang tuanya. Hal ini karena perhatian orang tua merupakansalah satu faktor untuk memotivasi anak. Keberhasilan belajar tentunya didasari karena motivasi, keinginan, dorongan dan minat yang terus menerus untuk mengerjakan suatu pekerjaan. Keinginan subjek untuk dapat membaca dengan lancar dan motivasi dari pihak orang tua atau keluarga cukup berpengaruh dalam proses belajar anak.

2. Faktor intelegensi maupun sosio-ekonomi

Hasil penelitian dapat melihat 2 dari 3 orang anak yang mengalami kesulitan membaca di kelas 2 dapat diketahui memang memiliki intelegensi yang rendah sehingga kemampuan dalam menginggat maupun menghafal sesuatu juga rendah. Dalam proses pembelajaran dapat dilihat perbedaan yang cukup mencolok antara anak-anak yang memiliki intelegensi yang tinggi dengan yang rendah, misalnya kecepatan pemahaman serta ketepatan dalam memberikan jawaban atas pertanyaan guru. Anak-anak yang memiliki intelengi yang rendah, akan kesulitan dalam mengikuti kegiatan pembelajaran di kelas, sehingga guru selalu mengulangi apa yang diajarkan. Kesulitan membaca pada subjek penelitian dipengaruhi pula dari faktor sosio-ekonomi yang dialami anak, sehingga kebiasaan belajar anak dan fasilitas anak yang diberikan di rumah juga kurang mendukung kegiatan belajar anak.

Ketertarikan anak dalam belajar membaca tentu juga harus didukung dengan fasilitas yang memadai maupun media yang mendukung dalam belajar. Berdasarkan hasil penelitian 2 dari 3 anak memang tergolong dalam keluarga yang secara sosio-ekonomi memiliki kekurangan, sehingga tidak dapat memberikan fasilitas yang lebih kepada anak dalam belajar dan ditambah lagi orang tua yang jarang sekali memberikan bimbingannya selama belajar. Nampak bahwa anakanak tersebut memiliki keengganan dalam belajar di rumah, sehingga proses belajar hanya dilakukan ketika di sekolah saja.

Pembelajaran anak disleksia dengan menggunakan metode SAS di kelas 2 SDN Watuaji 1 Jepara diawali dari proses struktural yakni dengan menampilkan keseluruhan (kalimat utuh), kalimat yang dipilih adalah kalimat yang cukup mudah, tidak membutuhkan banyak huruf yang bervariasi. Proses selanjutnya 
adalah analitik yang dilakukan dengan melakukan proses penguraian kalimat menjadi unsur bahasa terkecil, dan Sintetik dilakukan dengan cara penggabungan kembali kepada bentuk struktural semula. Metode struktural analitik sintetik pada dasarnya dilandasi oleh tiga landasan, yakni:

a. Landasan psikologis

Bahwa pengamatan pertama bersifat global (totalitas), dan bahwa anak usia sekolah memiliki sifat ingin tahu yang kuat. Mendasarkan pada landasan psikologis ini, anak yang mengalami kesulitan membaca pada dasarnya tetap merupakan anak yang memiliki rasa ingin tahu yang kuat, tinggal bagaimana rasa ingin tahu tersebut dimunculkan secara lebih dominan.

b. Landasan pedagogis

Landasan pedagogis dilakukan dengan mengembangkan potensi dan pengalaman anak, serta membimbing anak menemukan suatu masalah. Landasan pedagogis ini merupakan hal yang utama dilakukan terutama dengan mengidentifikasi penyebab anak mengalami kesulitan dalam membaca. Landasan pedagogis merupakan dasar utama untuk membantu anak dalam membimbing dan mengarahkan anak sesuai dengan penyebab anak mengalami kesulitan dalam membaca.

c. Landasan linguistik

Landasan linguistik mendasarkan bahwa ucapan bukan tulisan, sehingga unsur bahasa dalam metode struktural analitik sintetik ialah kalimat, dan kalimat dalam bahasa Indonesia mempunyai struktur tersendiri. Langkahlangkah implementasi metode SAS diawali dengan memberikan anak sebuah kata atau kalimat, kemudian anak diminta untuk mengeja kalimat menjadi kata, suku kata, mengurai kata itu menjadi huruf-huruf dan kegiatan tersebut diulangi sampai anak menyadari hubungan antara bunyi dan suku kata/ huruf. Dengan kegiatan mengeja, anak diharapkan dapat merangkai kembali huruf tersebut menjadi suku kata/ kata dan anak dapat membaca utuh kata tersebut. Dalam kegiatan pembelajaran, nampak bahwa anak-anak yang mengalami kesulitan dalam belajar membaca cukup tertarik dalam belajar menggunakan metode SAS, terutama dengan bimbingan langsung dari guru. Metode SAS memang diupayakan untuk dapat membantu anak memahami setiap bagian kalimat, kata maupun huruf dengan lebih mudah, sehingga metode ini cukup 
menarik bagi anak yang kesulitan dalam membaca. Adapun implementasinya dapat dilihat dalam gambar berikut:

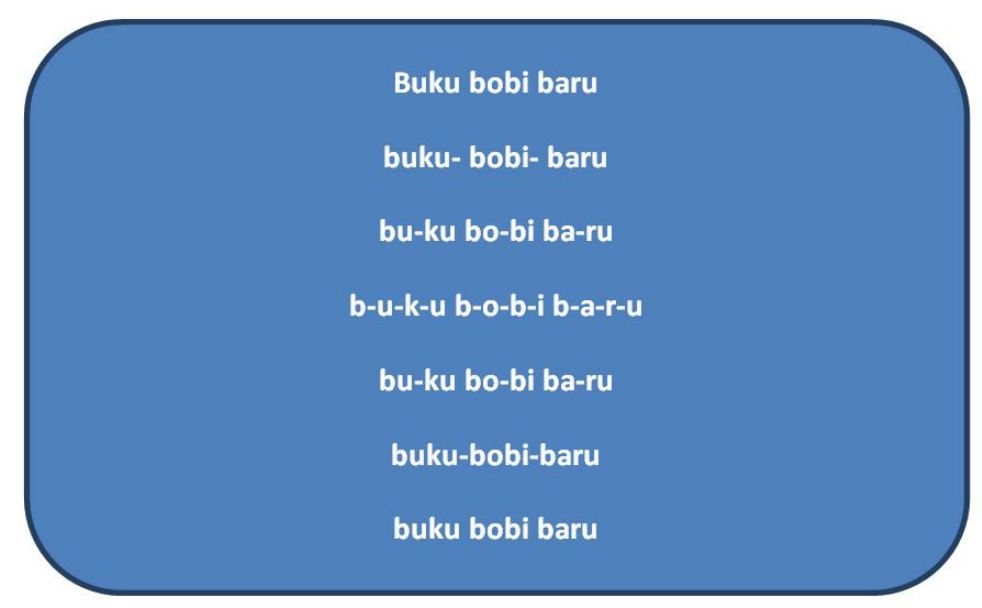

Gambar 1. Contoh kalimat yang digunakan menggunakan metode SAS

Metode SAS tentunya sejalan dengan prinsip linguistik (ilmu bahasa) yang memandang satuan bahasa terkecil yang bermakna untuk berkomunikasi adalah kalimat, bahwa pada hakikatnya kalimat merupakan suatu struktur. Oleh karena itu kepada siswa disajikan kalimat secara utuh, kemudian kalimat itu dianalisis menjadi unsur-unsur kalimat, yaitu kata, kata dianalisis menjadi suku kata, suku kata dianalisis menjadi huruf (unsur terkecil dari bahasa). Unsur terkecil berupa huruf itu, kemudian dirangkaikan kembali menjadi suku kata, suku kata dirangkai menjadi kata, dan akhirnya kata dirangkai menjadi kalimat. Dengan demikian, anak-anak akan menemukan kembali wujud struktur semula, yakni sebuah kalimat utuh. Jika dilihat prosesnya, metode ini merupakan campuran dari metode-metode membaca permulaan.

Implementasi metode SAS juga dilakukan dengan melibatkan temanteman yang sudah mampu membaca dengan baik, sehingga anak-anak yang sudah dapat membaca juga dapat memberikan bantuan kepada teman-temannya yang belum dapat membaca dengan lancar. Pelaksanaan metode SAS dapat divariasi dengan menggunakan kartu-kartu huruf, kartu kata, dan kartu kalimat. Adapun pemilihan huruf, kata dan kalimat juga disesuaikan dengan tingkat pemahaman siswa. Sementara anak-anak mencari huruf, suku kata, kata, guru dan sebagian siswa yang lain menempelkan kata-kata yang tersusun menjadi 
kalimat yang berarti. Begitu seterusnya sehingga semua anak mendapat giliran untuk menyusun kalimat, dan membacanya.

Adapun contoh kartu-kartu tersebut dapat dilihat dalam gambar 2 berikut:

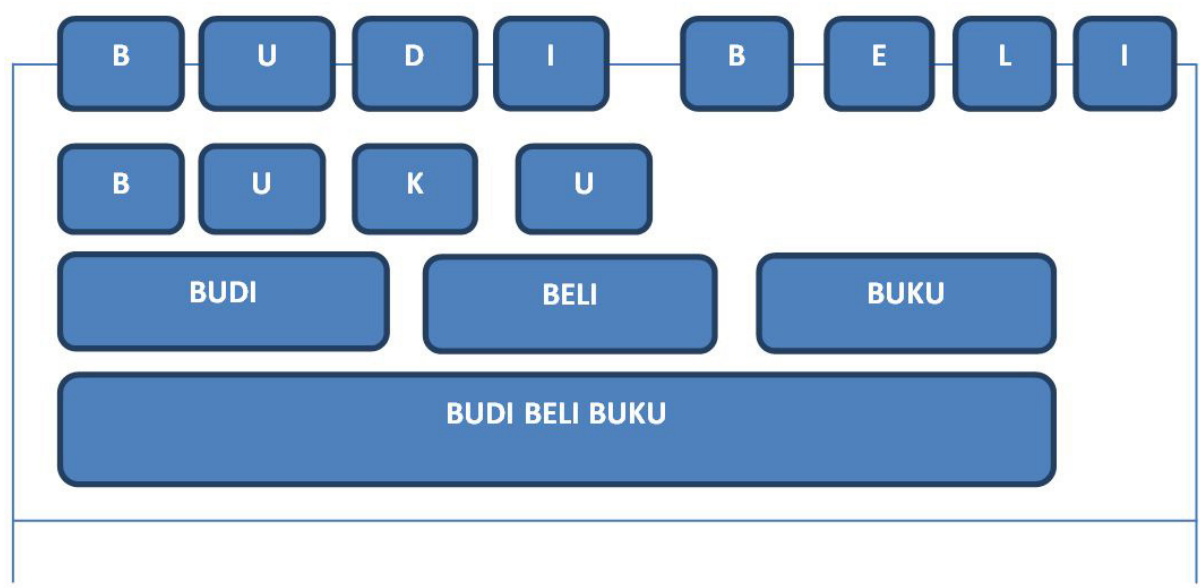

Gambar 2. Kartu huruf, kata, dan kalimat

Penggunaan kartu-kartu kata, huruf, dan kalimat dalam pembelajaran anak yang mengalami kesulitan membaca selain dapat membantu anak membaca dengan mudah, juga meningkatkan kerjasama anak dalam proses pembelajaran. Hal ini karena proses pembelajaran juga dilakukan dengan permainan yang melibatkan semua siswa, sehingga anak-anak yang mengalami kesulitan dalam membaca akan termotivasi untuk dapat membaca seperti temantemannya. Pembelajaran pada awalnya dilakukan melalui kelompok kecil di mana kelompok kecil terdiri dari 3 anak yang mengalami kesulitan membaca. Pembelajaran dalam kelompok kecil ini dilakukan secara rutin setiap hari selama dua minggu. Pembelajaran kemudian digabungkan dengan teman-temannya pada saat anak-anak yang mengalami kesulitan dalam membaca dirasa mampu memahami struktur kalimat dengan benar. Kegiatan ini dilakukan untuk memberikan pembiasaan anak yang kesulitan membaca untuk memahami struktur kalimat dengan lebih mudah. Kegiatan pembelajaran dengan sistem ini selain membantu anak-anak dalam membaca, juga meningkatkan interaksi sosial dan kerjasama antar siswa, bentuk kerjasamanya yang nampak dapat dilihat dari upaya anak-anak yang sudah dapat membaca dengan benar dan lancar untuk dapat membantu teman-temannya yang mengalami kesulitan dalam belajar membaca. 


\section{KESIMPULAN}

Berdasarkan hasil penelitian dapat diketahui bahwa kesulitan membaca pada anak kelas 2 SDN Watuaji 1 Jepara, dapat diketahui bahwa beberapa faktor penyebab kesulitan membaca disebabkan karena faktor kurangnya perhatian orang tua, faktor intelegensi dan sosio-ekonomi. Pelaksanaan metode SAS dalam pembelajaran anak disleksia dapat membantu anak dalam mempermudah belajar membaca. Pelaksanaan metode SAS dilakukan dengan menyajikan kalimat secara utuh, kemudian kalimat itu dianalisis menjadi kata, suku kata, dan dianalisis menjadi huruf dan unsur huruf tersebut dirangkaikan hingga menjadi kalimat kembali. Penggunaan metode SAS selain dapat membantu kesulitan membaca juga dapat meningkatkan kerjasama anak dalam proses pembelajaran.

\section{E. DAFTAR PUSTAKA}

Abdurrahman, Mulyono. Pendidikan Bagi anak Berkesulitan Belajar. Jakarta: Rineka Cipta, 2003.

Adhim, M. Fauzil. Membuat Anak Gila Membaca. Bandung: Mizan Media Utama, 2004.

Marhaeni. Metode Penelitian. Jakarta: PT. Bumi Aksara, 2005.

Moleong, J. Lexy. Metode Penelitian Kualitatif. Bandung: Remaja Rosdakarya, 2007.

Puji Santoso. Materi dan Pembelajaran Bahasa Indonesia SD. Jakarta: Universitas Terbuka, 2008.

Rahim, Farida. Pengajaran Membaca di Sekolah Dasar. Jakarta: Bumi Aksara, 2007.

Suryabrta, Sumadi. Psikologi Pendidikan. Jakarta: Grafindo, 2012.

Wassid, Iskandar, dan Dadang Sunendar. Strategi Pembelajaran Bahasa. Bandung: Remaja Rosdakarya, 2008. 